\title{
Saccharopolyspora ghardaiensis sp. nov., an extremely halophilic actinomycete isolated from Algerian Saharan soil
}

\author{
Atika Meklat ${ }^{1,2}$, Noureddine Bouras ${ }^{1}$, Abdelghani Zitouni ${ }^{1}$, Nasserdine Sabaou ${ }^{1}$, Florence Mathieu ${ }^{3}$, \\ Peter Schumann ${ }^{4}$, Cathrin Spröer ${ }^{4}$ and Hans-Peter Klenk ${ }^{4}$
}

A novel halophilic actinomycete, strain designated $\mathrm{H}^{5} 3^{\top}$, was isolated from a Saharan soil sample collected from Chaâbet Ntissa, Béni-isguen, Ghardaïa (South of Algeria) and was characterized taxonomically by means of polyphasic approach. Optimal growth was found to occur at $30-35^{\circ} \mathrm{C}, \mathrm{pH} 6-7$ and in the presence of $15-25 \%(\mathrm{w} / \mathrm{v}) \mathrm{NaCl}$. The strain was observed to produce abundant aerial mycelium, which formed long chains of rod-shaped spores at maturity, and well developed and fragmented substrate mycelium. The cell wall was determined to contain meso-diaminopimelic acid; the diagnostic whole-cell sugars were arabinose and galactose. The predominant menaquinones were found to be $M K-9\left(\mathrm{H}_{4}\right)$ and $M K-9\left(\mathrm{H}_{6}\right)$. The predominant cellular fatty acids were determined to be iso- and anteiso- $\mathrm{C}_{17: 0}$, iso- $\mathrm{C}_{15: 0}$, and cis9 iso- $\mathrm{C}_{17: 1}$. The diagnostic phospholipid detected was phosphatidylcholine. The morphological and chemotaxonomic characteristics of the strain were consistent with those of members of the genus Saccharopolyspora. Phylogenetic analyses on the basis of the $16 \mathrm{~S}$ ribosomal RNA (rRNA) gene sequence showed that this strain formed a distinct phyletic line within the radiation of the genus Saccharopolyspora. The 16S rRNA sequence similarities between strain $\mathrm{H}^{5} 3^{\top}$ and other members of the genus Saccharopolyspora ranged from 92.1 to $94.3 \%$. The DNA G + C content of strain $\mathrm{H}^{5} 3^{\top}$ was $72.6 \%$. The genotypic and phenotypic data showed that the strain $\mathrm{H}^{5} 3^{\mathrm{T}}$ represents a novel species of the genus Saccharopolyspora, for which the name Saccharopolyspora ghardaiensis sp. nov. is proposed, with the type strain $\mathrm{H}^{5} 3^{\top}$ ( $=\mathrm{DSM} 45606^{\top}=\mathrm{CCUG} 63370^{\top}=\mathrm{CECT}$ $8304^{\top}$ ).

The Journal of Antibiotics (2014) 67, 299-303; doi:10.1038/ja.2013.136; published online 18 December 2013

Keywords: Ghardaïa; halophilic actinomycete; Saccharopolyspora ghardaiensis; Saharan soil; taxonomy

\section{INTRODUCTION}

The genus Saccharopolyspora was first described by Lacey and Goodfellow $^{1}$ for actinomycetes isolated from spontaneously heated sugarcane bagasse, and was assigned to the family Pseudonocardiaceae. $^{2}$ Nevertheless, most species of this genus were isolated from soil samples. At the time of writing, the genus comprises 23 recognized species, with Saccharopolyspora hirsuta as the type species. ${ }^{1}$ Most species of the genus Saccharopolyspora were non-halophilic, and some of them were halotolerant. However, only these species of this genus were reported to be extremely halophilic: S. halophila, ${ }^{3}$ S. qijiaojingensis ${ }^{4}$ and S. lacisalsi. ${ }^{5}$

Members of the genus Saccharopolyspora were characterized by extensively branched substrate mycelium that may fragment into rod-shaped and non-motile elements, and aerial mycelium that may segment into bead-like chains of spores. The strains of this genus were characterized chemotaxonomically by the presence of meso-diaminopimelic acid in the cell wall, arabinose and galactose as diagnostic sugars in whole-cell hydrolysates (wall chemotype $\operatorname{IVA}^{6}$ ), iso and anteiso-branched chain fatty acids, major amounts of phosphatidylcholine (phospholipid pattern $\mathrm{PIII}^{7}$ ), and MK-9 $\left(\mathrm{H}_{4}\right)$ as the predominant menaquinone, but lack mycolic acids. ${ }^{8}$ The DNA base compositions of members of this genus fall within the range of 66-77 mol\% G + C. 9 Several strains and species belonging to the genus Saccharopolyspora produce different bioactive secondary metabolites, such as the enzyme inhibitor CL307-24 ${ }^{10}$ and the antimicrobial compounds erythromycin ${ }^{11}$ and spinosyns. ${ }^{12}$

During our investigation of actinomycetes from Saharan soils, the strain $\mathrm{H} 53^{\mathrm{T}}$ was isolated. This strain showed a good antibacterial and antifungal activity, especially against Bacillus subtilis (ATCC 6633), Micrococcus luteus (ATCC 9314) and Mucor ramannianus (NRRL 1829). In this paper we describe the characterization of new species in the genus Saccharopolyspora.

${ }^{1}$ Laboratoire de Biologie des Systèmes Microbiens (LBSM), Ecole Normale Supérieure de Kouba, Alger, Algeria; ${ }^{2}$ Faculté des sciences Agronomiques, Vétérinaires et Biologiques, Département de Biologie, Université Saâd Dahleb, Blida, Algeria; ${ }^{3}$ Université de Toulouse; INPT-ENSAT, Laboratoire de Génie Chimique; UMR 5503 (CNRS/INPT/UPS), Castanet-Tolosan, France and ${ }^{4}$ Leibniz Institute DSMZ-German Collection of Microorganisms and Cell Cultures, Braunschweig, Germany Correspondence: Dr N Sabaou, Laboratoire de Biologie des Systèmes Microbiens (LBSM), Ecole Normale Supérieure de Kouba, Alger 16050, Algeria. E-mail: sabaou@yahoo.fr

Received 29 May 2013; revised 23 October 2013; accepted 15 November 2013; published online 18 December 2013 


\section{MATERIALS AND METHODS}

\section{Isolation of actinomycete strain}

During our investigations on extremophilic actinomycetes diversity in Algerian Saharan soils, the halophilic strain $\mathrm{H} 53^{\mathrm{T}}$ was isolated from a non-saline soil sample (electrical conductivity $=0.15 \mathrm{mS} \mathrm{cm}^{-1}$ ) collected from Chaâbet Ntissa $\left(32^{\circ} 27^{\prime} 52^{\prime \prime} \mathrm{N}, 3^{\circ} 40^{\prime} 19^{\prime \prime} \mathrm{E}\right)$, Béni-isguen (Mzab), Ghardaïa province (South of Algeria), by a dilution-plate agar method using humic acid-vitamin agar medium ${ }^{13}$ supplemented with actidione $\left(50 \mathrm{mgl}^{-1}\right)$ and $20 \%(\mathrm{w} / \mathrm{v}) \mathrm{NaCl}$ at $30^{\circ} \mathrm{C}$ for 45 days. The strain, which formed a white colony, was purified and maintained at $4{ }^{\circ} \mathrm{C}$ on complex medium $(\mathrm{CM})$ agar $^{14}$ containing $20 \%(\mathrm{w} / \mathrm{v})$ $\mathrm{NaCl}$. Strain $\mathrm{H} 53^{\mathrm{T}}$ was deposited in the German Collection of Microorganisms and Cell Cultures as strain DSM $45606^{\mathrm{T}}$, in the Culture Collection, University of Göteborg, as strain CCUG $63370^{\mathrm{T}}$, and in the Spanish Type Culture Collection as strain CECT $8304^{\mathrm{T}}$.

\section{Cultural and micro-morphological characteristics}

Cultural characteristics of strain $\mathrm{H} 53^{\mathrm{T}}$ were investigated after 7, 14 and 21 days of incubation at $30^{\circ} \mathrm{C}$ using the media of the International Streptomyces Project, ISP 2 and ISP $4,{ }^{15} \mathrm{CM}$ agar $^{14}$ and nutrient agar (bacteriological peptone, $5 \mathrm{~g}$; meat extract, $1 \mathrm{~g}$; yeast extract, $2 \mathrm{~g} ; \mathrm{NaCl}, 5 \mathrm{~g}$; agar, $18 \mathrm{~g}$; in $1000 \mathrm{ml}$ deionized water; $\mathrm{pH}$ 7.2). The colors of the substrate, and aerial mycelia and any soluble pigments produced were determined by comparison with ISCC-NBS color charts. ${ }^{16}$ The morphological characteristics of strain $\mathrm{H} 53^{\mathrm{T}}$, including spore size, spore-chain morphology and surface ornamentation, were examined by light microscope (Motic, B1 Series, Hong Kong) and scanning electron microscope (model S450; Hitachi, Japan) after two weeks growth on ISP 2 medium at $30^{\circ} \mathrm{C}$. All media used for morphological characteristics contained $15 \%(\mathrm{w} / \mathrm{v}) \mathrm{NaCl}$.

\section{Physiological characterization}

Physiological tests were used to characterize the actinomycete strain $\mathrm{H} 53^{\mathrm{T}}$ in comparison with its closest relative halophilic species (S. lacisalsi TRM $40133^{\mathrm{T}}$ and S. qijiaojingensis YIM $\left.91168^{\mathrm{T}}\right)$. Growth at different temperatures $(10,15$, $20,25,28,30,32,35,40,45$ and $\left.47^{\circ} \mathrm{C}\right)$, various $\mathrm{pH}$ values $(5,6,7,8$ and 9) and $\mathrm{NaCl}$ concentrations $(0,7,10,15,20,25,28,30,32$ and 35\%; w/v), and also in the presence of antibiotics, were determined by using nutrient agar medium, with the cultures incubated for 21 days at $30^{\circ} \mathrm{C}$. All media used for physiological tests contained $15 \%(\mathrm{w} / \mathrm{v}) \mathrm{NaCl}$ (except for the $\mathrm{NaCl}$ concentration test). Production of acid from carbohydrates, and decarboxylation of organic acids were studied using the method of Gordon et al. ${ }^{17}$ Degradation of different other organic compounds was evaluated as described by Goodfellow. ${ }^{18}$ Lysozyme sensitivity and production of nitrate reductase were determined according to the methods of Gordon and Barnett ${ }^{19}$ and Marchal et al., ${ }^{20}$ respectively. The production of melanoid pigments was evaluated on ISP 6 and ISP 7 media as recommended by Shirling and Gottlieb. ${ }^{15}$

\section{Chemotaxonomic characterization}

For the chemotaxonomic analyses, strain $\mathrm{H} 53^{\mathrm{T}}$ was grown in $\mathrm{CM}$ broth containing $15 \%(\mathrm{w} / \mathrm{v}) \mathrm{NaCl}$ at $30^{\circ} \mathrm{C}$ for 10 days on a rotary shaker (250 r.p.m.). Biomass was harvested by centrifugation at 3500 r.p.m. and washed several times with distilled water. The isomeric form of diaminopimelic acid and the presence (or absence) of glycine in the cell wall were realized as described by Becker et $a l^{21}$ The composition of whole-cell sugars was determined as described by Lechevalier and Lechevalier. ${ }^{6}$ Polar lipids were determined according to the method described by Minnikin et $a l^{22}$ and separated by two dimensional TLC. The menaquinones were extracted according to the procedure of Minnikin et al..$^{23}$ and were analyzed by HPLC. $^{24,25}$ For extraction and analysis of cellular fatty acids, the physiological age of the strain was standardized by consistently choosing the same factor (the last quadrant streaked) on $(\mathrm{CM}+\mathrm{YE}$ medium, see DSMZ web pages, https://www.dsmz.de/catalogues/catalogue-microorganisms/ culture-technology/list-of-media-for-microorganisms.html) incubated at $28{ }^{\circ} \mathrm{C}$ for 10 days. The analysis was conducted using the Microbial Identification System (MIDI) Sherlock software version 4.5 (method TSBA40, TSBA6 database) as described by Sasser. ${ }^{26}$ The analysis of mycolic acids was performed using the method of Minnikin et al. ${ }^{27}$

\section{Determination of $16 \mathrm{~S}$ ribosomal RNA gene sequence and} phylogenetic analyses

For DNA analysis, the strain $\mathrm{H} 53^{\mathrm{T}}$ was grown on the $\mathrm{CM}$ broth supplemented with $15 \%(\mathrm{w} / \mathrm{v}) \mathrm{NaCl}$. The genomic DNA was extracted with DNA extraction kit (JetFlex, Hannover, Germany) according to the method of Liu et al. ${ }^{28}$ PCR-mediated amplification of the $16 \mathrm{~S}$ ribosomal RNA (rRNA) gene and sequencing of the purified PCR products were carried out as described by Rainey et al. ${ }^{29}$ PCR products were purified with a PCR product purification kit (Qiagen, Hilden, Germany). The primers used for sequencing are listed in Coenye et al. ${ }^{30}$ The 16S rRNA sequence has been deposited in the GenBank data library and assigned the accession number KC427277. The sequences obtained were compared with sequences present in the public sequence databases as well as with the EzTaxon-e server (http://eztaxon-e. ezbiocloud.net $/{ }^{31}$ ), a web-based tool for the identification of prokaryotes based on $16 \mathrm{~S}$ rRNA gene sequences from type strains. Phylogenetic analyses were conducted using MEGA version $5 .^{32}$ The $16 \mathrm{~S}$ rRNA sequence of strain $\mathrm{H} 53^{\mathrm{T}}$ was aligned using the CLUSTAL $\mathrm{W}^{33}$ against corresponding nucleotide sequences retrieved from GenBank. Phylogenetic trees were constructed by using the neighbor joining ${ }^{34}$ with Jukes and Cantor $^{35}$ model, maximum likelihood ${ }^{36}$ with Kimura two-parameter ${ }^{37}$ model and maximum-parsimony ${ }^{38}$ methods. The topology of the tree was evaluated by bootstrap analysis based on 1000 replicates. ${ }^{39}$

\section{Determination of $\mathbf{G}+\mathrm{C}$ content of DNA}

The $\mathrm{G}+\mathrm{C}$ content of the chromosomal DNA was determined by HPLC according to Mesbah et al. ${ }^{40}$

\section{RESULTS AND DISCUSSION}

Morphological characteristics

Strain $\mathrm{H} 53^{\mathrm{T}}$ was observed to grow well on ISP 2, nutrient agar and CM agar media, and the aerial mycelium was moderately abundant with white color on these media. However, poor growth was observed on ISP 4 medium. Substrate mycelium was dark reddish orange color on ISP 2 and nutrient agar media, and was light yellow on CM agar and ISP 4 media. Melanoid pigments and other diffusible pigments were not produced on tested media (ISP 6, ISP 7 and other media).

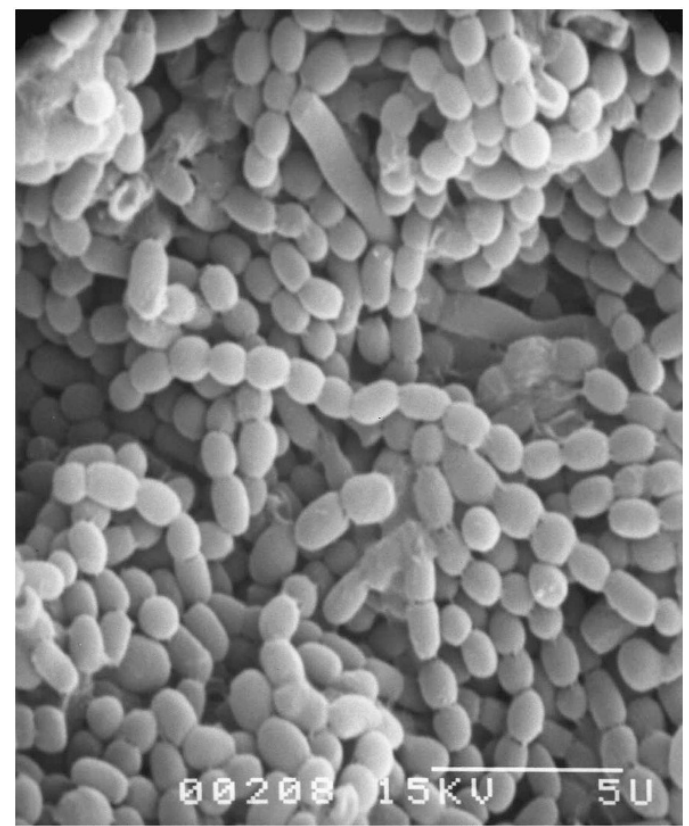

Figure 1 Scanning electron micrograph of strain $\mathrm{H}_{5} 3^{\top}$ showing long spore chains of smooth surface spores after 15 days growth at $30^{\circ} \mathrm{C}$ on yeast extract-malt extract agar (ISP 2) containing 15\% (w/v) NaCl. Bar $=5 \mu \mathrm{m}$. 
The substrate mycelium was well developed and fragmented into non-motile cocci. It exhibited an abundant fragmentation on both solid and liquid media. Aerial mycelia form long chains of spores that are non-motile, smooth surfaced, oval or spherical in shape (Figure 1). No morphological forms or structures resembling sporangia, sclerotia or synnemata were observed.

\section{Chemotaxonomic characteristics}

Strain $\mathrm{H} 53^{\mathrm{T}}$ was determined to contain meso-diaminopimelic acid (but not glycine) in its cell wall. Whole-cell hydrolysates were found to contain arabinose and galactose (chemotype pattern IVA of Lechevalier and Lechevalier). ${ }^{6}$ Furthermore, the presence of ribose was also confirmed. Mycolic acids were not detected. The phospholipids detected were phosphatidylcholine (in very small amount), diphosphatidylglycerol, phosphatidylglycerol and phosphatidylinositol, as well as several glycolipids and unknown phospholipid (Supplementary Figures S1a and b). This polar lipid pattern corresponds to phospholipid type III. $^{7}$ The predominant menaquinones were determined to be MK-9 $\left(\mathrm{H}_{4}\right)$ (88.9\%) and MK-9 $\left(\mathrm{H}_{6}\right)$ (4.6\%), and minor amounts of MK-9 $\left(\mathrm{H}_{2}\right)$, MK-9 $\left(\mathrm{H}_{8}\right)$, as well as unidentified menaquinones were also detected. The fatty acid's profile was composed as follows: anteiso- $\mathrm{C}_{17: 0}(27.8 \%)$, iso- $\mathrm{C}_{15: 0}(26.2 \%)$, iso- $\mathrm{C}_{17: 0}(14.0 \%)$, cis 9 iso- $\mathrm{C}_{17: 1}(11.7 \%)$, iso- $\mathrm{C}_{16: 0}$ $(5.6 \%)$ and anteiso- $\mathrm{C}_{15: 0}(3.5 \%)$ (Supplementary Table S1). The morphological and chemical characteristics described above clearly support the placement of strain $\mathrm{H}_{5} 3^{\mathrm{T}}$ within the genus Saccharopolyspora.

\section{Physiological characteristics}

The strain $\mathrm{H}_{5} 3^{\mathrm{T}}$ grew in a wide range of $\mathrm{NaCl}$ concentrations $(7-32 \% \mathrm{w} / \mathrm{v}$ on nutrient agar medium) and was strictly halophilic. It used the majority of sugars and other organic compounds for its growth. The organism is resistant to kanamycin $\left(5 \mu \mathrm{g} \mathrm{ml}^{-1}\right)$, erythromycin $\left(10 \mu \mathrm{g} \mathrm{ml}^{-1}\right)$, streptomycin $\left(10 \mu \mathrm{g} \mathrm{ml}^{-1}\right)$, penicillin $\left(25 \mu \mathrm{g} \mathrm{ml}^{-1}\right)$ and lysozyme $(0.005 \% \mathrm{w} / \mathrm{v})$, but sensitive to chloramphenicol $\left(25 \mu \mathrm{g} \mathrm{ml}^{-1}\right)$. The complete physiological characteristics of strain $\mathrm{H} 53^{\mathrm{T}}$ are given in the species description.

\section{Phylogenetic analysis based on 16S rRNA gene sequence comparison and $\mathrm{G}+\mathrm{C}$ content of DNA}

Phylogenetic analysis of an almost complete 16S rRNA gene sequence (1491 bp, GenBank accession number KC427277) showed that strain

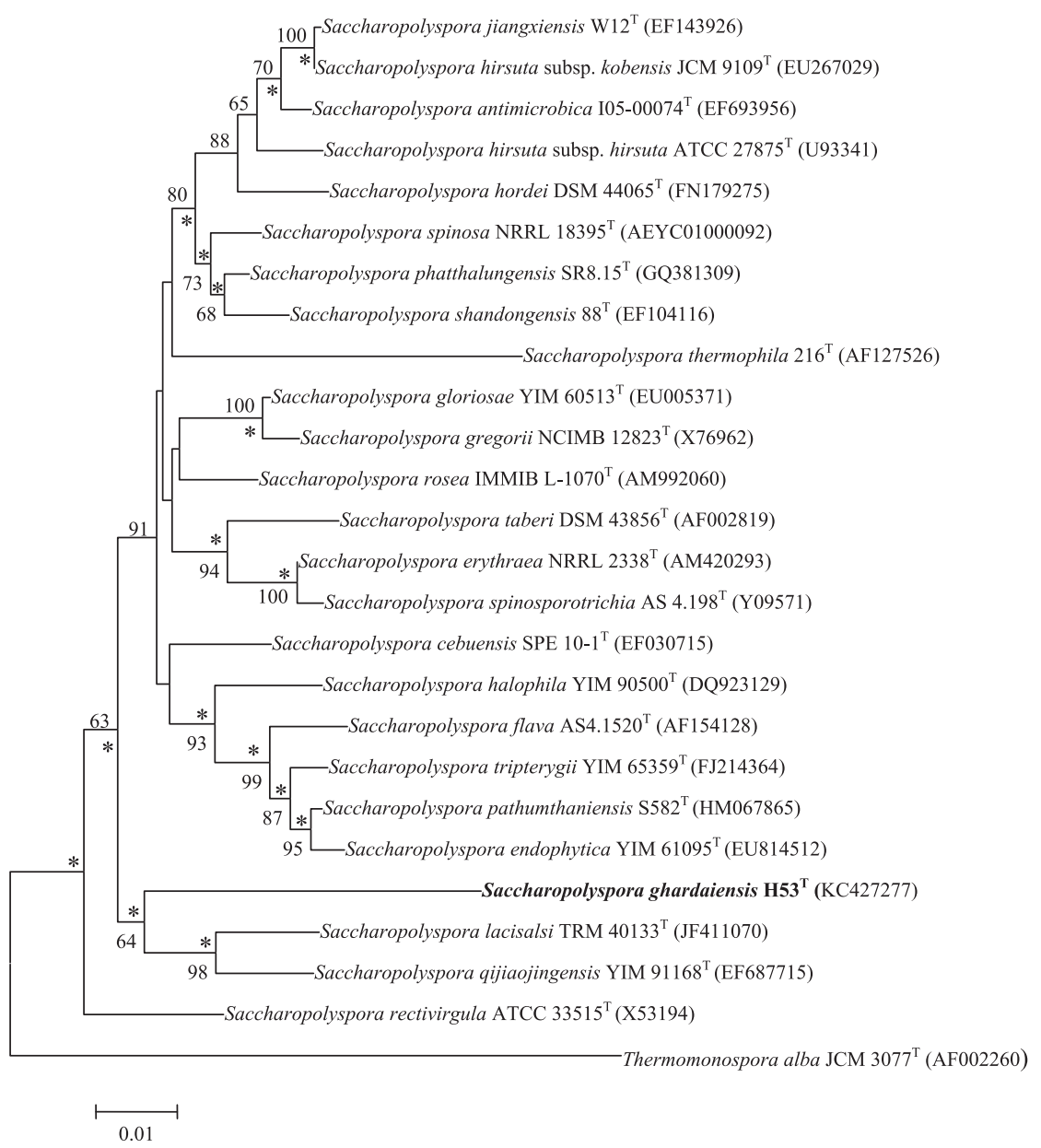

Figure 2 Phylogenetic tree for species of the genus Saccharopolyspora calculated from almost complete 16S rRNA gene sequences using Jukes and Cantor ${ }^{35}$ evolutionary distance methods and the neighbor-joining method of Saitou and Nei. ${ }^{34}$ This illustrates the taxonomic position of strain $\mathrm{H} 53^{\top}$ relative to the other species of the genus. Asterisks indicate branches that are conserved when the neighbor-joining, maximum-parsimony and maximum-likelihood methods were used in constructing phylogenetic trees. Numbers at the nodes are bootstrap values, expressed as a percentage of 1000 resamplings (only values $>50 \%$ are shown). Bar $=0.01$ nucleotide substitutions per site. 
$\mathrm{H} 53^{\mathrm{T}}$ was related to members of the genus Saccharopolyspora. Moreover, the 16S rRNA sequence similarities between strain $\mathrm{H} 53^{\mathrm{T}}$ and other species of the genus Saccharopolyspora ranged from 92.1 to $94.3 \%$. The phylogenetic relationship between strain $\mathrm{H} 53^{\mathrm{T}}$ and the other Saccharopolyspora species is seen in the neighbor-joining dendrogram (Figure 2). Maximum parsimony and maximum-likelihood calculation resulted in a similar tree topology.

The strain $\mathrm{H}_{5} 3^{\mathrm{T}}$ has a DNA G $+\mathrm{C}$ content of $72.6 \mathrm{~mol} \%$.

\section{CONCLUSION}

The results of the morphological and chemotaxonomic investigations and phylogenetic analysis supported the affiliation of the strain $\mathrm{H} 53^{\mathrm{T}}$ to the genus Saccharopolyspora. The comparison with S. lacisalsi TRM $40133^{\mathrm{T}}$ showed differences in the color of substrate mycelium, the $\mathrm{G}+\mathrm{C}$ content, the decomposition of adenine, hypoxanthine, gelatin, starch and tyrosine, the growth at $45^{\circ} \mathrm{C}$, and the growth with $28,30,32$ and $35 \% \mathrm{NaCl}(\mathrm{w} / \mathrm{v})$ on nutrient agar medium as shown in Table 1. Furthermore, the differences in the production of acids from the utilization of L-arabinose, D-fructose, D-lactose, Dmannitol and D-xylose were observed. In addition, a comparison with the S. qijiaojingensis YIM $91168^{\mathrm{T}}$ showed differences in the color of substrate mycelium, the $\mathrm{G}+\mathrm{C}$ content, the decomposition of adenine, gelatin, starch, Tween 80 , tyrosine and xanthine, the production of nitrate reductase, the growth at $45^{\circ} \mathrm{C}$, and the

Table 1 Differential phenotypic characteristics of strain $\mathrm{H}^{5} 3^{\mathrm{T}}$ compared with its closest relative halophilic species (S. lacisalsi TRM $40133^{\mathrm{T}}$ and S. qijiaojingensis YIM $91168^{\mathrm{T}}$ )

\begin{tabular}{|c|c|c|c|}
\hline Characteristics & 1 & 2 & 3 \\
\hline $\begin{array}{l}\text { Color of substrate mycelium on } \\
\text { ISP } 2 \text { and nutrient agar media }\end{array}$ & $\begin{array}{l}\text { Dark reddish } \\
\text { orange, light yellow }\end{array}$ & White-yellow & White-yellow \\
\hline \multicolumn{4}{|l|}{ Utilization of } \\
\hline L-Arabinose & + & - & - \\
\hline D-Cellobiose & + & + & - \\
\hline D-Fructose & + & - & - \\
\hline D-Lactose & + & - & + \\
\hline D-Mannitol & - & + & + \\
\hline L-Rhamnose & - & - & + \\
\hline Sucrose & + & + & - \\
\hline D-Xylose & + & - & - \\
\hline \multicolumn{4}{|l|}{ Degradation of } \\
\hline Adenine & + & - & - \\
\hline Hypoxanthine & + & - & + \\
\hline Gelatin & - & + & + \\
\hline Starch & + & - & - \\
\hline Tween 80 & + & + & - \\
\hline Tyrosine & + & - & - \\
\hline Xanthine & - & - & + \\
\hline Production of nitrate reductase & + & + & - \\
\hline Temperature range $\left({ }^{\circ} \mathrm{C}\right)$ & $25-45$ & $25-40$ & $20-40$ \\
\hline $\mathrm{pH}$ range $(\%, w / v)$ & $5-8$ & $6-8$ & $5-8$ \\
\hline $\mathrm{NaCl}$ range $(\%, w / v)$ & $7-32$ & $5-25$ & $6-22$ \\
\hline DNA G $+C$ content ( $\mathrm{mol} \%$ ) & 72.6 & 68.2 & 70.1 \\
\hline
\end{tabular}

Abbreviations: - , negative; + , positive.

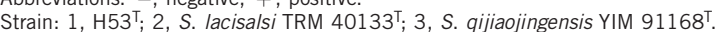

Data were from this study, except those of S. qijiaojingensis YIM $91168^{\mathrm{T}}$ : taken from Tang et $a .^{4}$ growth with $25,28,30,32$ and $35 \% \mathrm{NaCl}(w / v)$ on nutrient agar medium as shown in Table 1. Moreover, the differences in the production of acids from the utilization of L-arabinose, D-cellobiose, D-fructose, D-mannitol, L-rhamnose, sucrose and xylose were also observed.

All of the data support the designation of strain $\mathrm{H} 53^{\mathrm{T}}$ as representing a novel species of the genus Saccharopolyspora, for which the name Saccharopolyspora ghardaiensis sp. nov. is proposed.

\section{Description of $S$. ghardaiensis sp. nov.}

S. ghardaiensis (ghar.da.i.en'sis. N.L. fem. adj. ghardaiensis, pertaining to Ghardaïa, the source of the soil from which the type strain was isolated).

Halophilic filamentous actinomycete, aerial mycelium is white color on ISP 2, nutrient agar and CM agar media. The color of the substrate mycelium is dark reddish orange on ISP 2 and nutrient agar media, and is light yellow on CM agar medium. The substrate mycelium was well developed and fragmented into non-motile cocci. The aerial mycelia form long chains of non-motile, smooth-surfaced and oval (or spherical) spores. Melanoid and other diffusible pigments are not produced in tested media. Growth occurs at 25, 28, 30, 35, 40 and $45^{\circ} \mathrm{C}$ (but not at 10,15, 20 and $47^{\circ} \mathrm{C}$ ), and 30 to $35{ }^{\circ} \mathrm{C}$ is the optimal temperature among the tested ones. Moreover, the growth occurs at $\mathrm{pH} 5,6,7$ and 8 (but not at pH 4 and 9), and $\mathrm{pH} \mathrm{6-7}$ is the optimal $\mathrm{pH}$ among the tested ones. Acetate, adenine, citrate, hypoxanthine, starch, testosterone and Tween 80 are degraded. Casein, gelatin, guanine and xanthine are not decomposed. Utilizes L-arabinose, D-cellobiose, erythritol, D-fructose, D-galactose, D-glucose, glycerol, maltose, adonitol, D-lactose, meso-inositol, D-mannose, D-trehalose, sucrose and D-xylose as carbon sources for growth and acid production, but not D-mannitol, D-melezitose, melibiose, D-raffinose, L-rhamnose, D-ribose, salicin and D-sorbitol. Benzoate, butyrate, oxalate, propionate, pyruvate, succinate and tartrate were not decarboxylated. L-alanine, L-proline, L-serine and tyrosine are used as a source of nitrogen. Nitrate reductase is produced. Growth occurs on nutrient agar medium in the presence of $\mathrm{NaCl}$ at $7,10,15,20,25,28,30$ and $32 \%$, but not at 0 and $35 \%$ $(\mathrm{w} / \mathrm{v})$, and $15-25 \% \mathrm{NaCl}(\mathrm{w} / \mathrm{v})$ is the optimal concentration among the tested ones. Moreover, the growth occurs in the presence of kanamycin $\left(5 \mu \mathrm{g} \mathrm{ml}^{-1}\right)$, erythromycin $\left(10 \mu \mathrm{g} \mathrm{ml}^{-1}\right)$, streptomycin $\left(10 \mu \mathrm{g} \mathrm{ml}^{-1}\right)$ and penicillin $\left(25 \mu \mathrm{g} \mathrm{ml}^{-1}\right)$, and also in the presence of $0.005 \%$ lysozyme, but not in the presence of chloramphenicol $\left(25 \mu \mathrm{g} \mathrm{ml}^{-1}\right)$. Chemotype IVA (meso-diaminopimelic acid, arabinose and galactose in whole-cell hydrolysates), the diagnostic phospholipid, is phosphatidylcholine. The predominant menaquinones are MK$9\left(\mathrm{H}_{4}\right)$ and MK-9 $\left(\mathrm{H}_{6}\right)$. The predominant cellular fatty acids are anteiso- $\mathrm{C}_{17: 0}$, iso- $\mathrm{C}_{15: 0}$, iso- $\mathrm{C}_{17: 0}$ and cis 9 iso- $\mathrm{C}_{17: 1}$ The DNA G+C content of strain $\mathrm{H} 53^{\mathrm{T}}$ was $72.6 \%$. The type strain $\mathrm{H} 53^{\mathrm{T}}$ (= DSM $45606^{\mathrm{T}}=$ CCUG $63370^{\mathrm{T}}=$ CECT $8304^{\mathrm{T}}$ ) is isolated from a Saharan soil sample collected from Ghardaïa province (South Algeria). The GenBank accession number for the $16 \mathrm{~S}$ rRNA gene sequence of strain $\mathrm{H} 53^{\mathrm{T}}$ is $\mathrm{KC} 427277$.

\section{ACKNOWLEDGEMENTS}

We would like to gratefully acknowledge Dr Tong-Wei Guan (Xihua University, Chengdu, China) for providing the type strain of S. lacisalsi TRM $40133^{\mathrm{T}}$. We are also grateful to Gabriele Pötter (DSMZ) for growing S. ghardaiensis cultures and for assistance with chemotaxonomical analyses. Also, we are grateful to Djaber Hadj Saïd for providing the soil sample from Chaâbet Ntissa (Ghardaïa). 
1 Lacey, J. \& Goodfellow, M. A novel actinomycete from sugarcane bagasse: Saccharopolyspora hirsuta gen. et sp. nov. J. Gen. Microbiol. 88, 75-85 (1975).

2 Warwick, S. T., Bowen, T., McVeigh, H. \& Embley, T. M. A phylogenetic analysis of the family Pseudonocardiaceae and the genera Actinokineospora and Saccharothrix with 16S rRNA sequences and a proposal to combine the genera Amycolata and Pseudonocardia in an emended genusPseudonocardia. Int. J. Syst. Bacteriol. 44, 293-299 (1994).

3 Tang, S. K. et al. Saccharopolyspora halophila sp. nov., a novel halophilic actinomycete isolated from a saline lake in China. Int. J. Syst. Evol. Microbiol. 59, 555-558 (2009).

4 Tang, S. K. et al. Saccharopolyspora qijiaojingensis sp. nov., halophilic actinomycete isolated from a salt lake. Int. J. Syst. Evol. Microbiol. 59, 2166-2170 (2009).

5 Guan, T. W. et al. Saccharopolyspora lacisalsi sp. nov., a novel halophilic actinomycete isolated from a salt lake in Xinjiang, China. Extremophiles 15, 373-378 (2011).

6 Lechevalier, M. P. \& Lechevalier, H. A. Chemical composition as a criterion in the classification of aerobic actinomycetes. Int. J. Syst. Bacteriol. 34, 435-444 (1970).

7 Lechevalier, M. P., De Bièvre, C. \& Lechevalier, H. A. Chemotaxonomy of aerobic actinomycetes: phospholipid composition. Biochem. Syst. Ecol. 5, 249-260 (1977).

8 Embley, T. M., Wait, R., Dobson, G. \& Goodfellow, M. Fatty acid composition in the classification of Saccharopolyspora hirsuta. FEMS. Microbiol. Lett. 41, 131-135 (1987).

9 Goodfellow, M., Lacey, J., Athalye, M., Embley, T. M. \& Bowen, T. Saccharopolyspora gregorii and Saccharopolyspora hordei: two new actinomycete species from fodder. J. Gen. Microbiol. 135, 2125-2139 (1989).

10 Fabre, B., Velours, J., Etienne, G., Legendre, F. \& Tiraby, G. CL307-24, a new antibiotic complex from Saccharopolyspora aurantiaca sp. nov. II: Physico-chemical and biological properties. J. Antibiot. (Tokyo) 46, 1421-1427 (1993).

11 Tang, S. K. et al. Actinopolyspora alba sp. nov. and Actinopolyspora erythraea sp. nov. isolated from a salt field, and reclassification of Actinopolyspora iraqiensis Ruan et al. 1994 as a heterotypic synonym of Saccharomonospora halophila. Int. J. Syst. Evol. Microbiol. 61, 1693-1698 (2011).

$12 \mathrm{Kim}, \mathrm{H}$. J. et al. Biosynthesis of Spinosyn in Saccharopolyspora spinosa: synthesis of permethylated rhamnose and characterization of the functions of $\mathrm{SpnH}, \mathrm{Spnl}$, and SpnK. J. Am. Chem. Soc. 132, 2901-2903 (2010).

13 Hayakawa, M. \& Nonomura, H. Humic acid-vitamin agar, a new medium for the selective isolation of soil actinomycetes. J. Ferment. Technol. 65, 501-509 (1987).

14 Chun, J. et al. Nocardiopsis kunsanensis sp. nov., a moderately halophilic actinomycete isolated from a saltern. Int. J. Syst. Evol. Microbiol. 50, 1909-1913 (2000).

15 Shirling, E. B. \& Gottlieb, D. Methods for characterization of Streptomyces species. Int. J. Syst. Bacteriol. 16, 313-340 (1966).

16 Kelly, K. L. \& Judd, D. B. Color. Universal Language and Dictionary of Names (National Bureau of Standards Special Publication 440) (US Department of Commerce, Washington, DC, USA, 1976).

17 Gordon, R. E., Barnett, D. A., Handerhan, J. E. \& Pang, C. H. N. Nocardia coeliaca, Nocardia autotrophica, and the nocardin strain. Int. J. Syst. Bacteriol. 24, 54-63 (1974).

18 Goodfellow, M. Numerical taxonomy of some nocardioform bacteria. J. Gen. Microbiol. 69, 33-90 (1971).

19 Gordon, R. E. \& Barnett, D. A. Resistance to rifampicin and lysozyme of strains of some species of Mycobacterium and Nocardia as a taxonomic tool. Int. J. Syst. Bacteriol. 27, 176-178 (1977).

20 Marchal, N., Bourdon, J. L. \& Richard, C. L. Les milieux de culture pour l'isolement et l'identification biochimique des bactéries (Doin Press, Paris, France, 1987).
21 Becker, B., Lechevalier, M. P., Gordon, R. E. \& Lechevalier, H. A. Rapid differentiation between Nocardia and Streptomyces by paper chromatography of whole-cell hydrolysates. Appl. Microbiol. 12, 421-423 (1964).

22 Minnikin, D. E., Patel, P. V., Alshamaony, L. \& Goodfellow, M. Polar lipid composition in the classification of Nocardia and related bacteria. Int. J. Syst. Bacteriol. 27, 104-117 (1977).

23 Minnikin, D. E. et al. An integrated procedure for the extraction of bacterial isoprenoid quinones and polar lipids. J. Microbiol. Methods 2, 233-241 (1984).

24 Kroppenstedt, R. M. Separation of bacterial menaquinones by HPLC using reverse phase (RP18) and a silver loaded ion exchanger as stationary phases. J. Liq. Chromatogr. 5, 2359-2367 (1982).

25 Kroppenstedt, R. M. Fatty acid and menaquinone analysis of actinomycetes and related organisms. In Chemical Methods in Bacterial Systematics (eds Goodfellow, M. \& Minnikin, D. E.) 173-179 (Academic Press, London, UK, 1985).

26 Sasser, M. Identification of bacteria by gas chromatography of cellular fatty acids MIDI Technical Note $101 \mathrm{MIDI}$, Inc, North Newark, DE, USA, 1990).

27 Minnikin, D. E., Hutchinson, I. G., Caldicott, A. B. \& Goodfellow, M. Thin layer chromatography of methanolysates of mycolic acid-containing bacteria. J. Chromatogr. A 188, 221-233 (1980).

28 Liu, D., Coloe, S., Baird, R. \& Pedersen, J. Rapid mini-preparation of fungal DNA for PCR. J. Clin. Microbiol. 38, 471 (2000).

29 Rainey, F. A., Ward-Rainey, N., Kroppenstedt, R. M. \& Stackebrandt, E. The genus Nocardiopsis represents a phylogenetically coherent taxon and a distinct actinomycete lineage: proposal of Nocardiopsaceae fam. nov. Int. J. Syst. Bacteriol. 46, 1088-1092 (1996).

30 Coenye, T. et al. Classification of Alcaligenes faecalis-like isolates from the environment and human clinical samples as Ralstonia gilardii sp. nov. Int. J. Syst. Bacteriol. 49, 405-413 (1999).

$31 \mathrm{Kim}, \mathrm{O}$. S. et al. Introducing EzTaxon-e: a prokaryotic 16S rRNA Gene sequence database with phylotypes that represent uncultured species. Int. J. Syst. Evol. Microbiol. 62, 716-721 (2012).

32 Tamura, K. et al. MEGA5: molecular evolutionary genetics analysis using maximum likelihood, evolutionary distance, and maximum parsimony methods. Mol. Biol. Evol. 28, 2731-2739 (2011).

33 Larkin, M. A. et al. CLUSTAL W and CLUSTAL X version 2. Bioinformatics 23, 2947-2948 (2007).

34 Saitou, N. \& Nei, M. The neighbor-joining method: a new method for reconstructing phylogenetic trees. Mol. Biol. Evol. 4, 406-425 (1987).

35 Jukes, T. H. \& Cantor, C. R. Evolution of protein molecules. In Mammalian Protein Metabolism (ed Munro, H. N.) 21-132 (Academic Press, New York, NY, USA, 1969).

36 Felsenstein, J. Evolutionary trees from DNA sequences: a maximum likelihood approach. J. Mol. Evol. 17, 368-376 (1981).

37 Kimura, M. A simple method for estimating evolutionary rates of base substitutions through comparative studies of nucleotide sequences. J. Mol. Evol. 16, 111-120 (1980).

38 Fitch, W. M. On the problem of discovering the most parsimonious tree. Am. Nat. 111, 223-257 (1977).

39 Felsenstein, J. Confidence limits on phylogenies: an approach using the bootstrap. Evolution 39, 783-791 (1985).

40 Mesbah, M., Premachandran, U. \& Whitman, W. B. Precise measurement of the $\mathrm{G}+\mathrm{C}$ content of deoxyribonucleic acid by high-performance liquid chromatography. Int. J. Syst. Bacteriol. 39, 159-167 (1989).

Supplementary Information accompanies the paper on The Journal of Antibiotics website (http://www.nature.com/ja) 